\title{
Determinants of Adoption of Enterprise Resource Planning Systems by Listed Companies in Kenya
}

\author{
Malonza, Gladys Nduku Phd (Candidate), Dr. David Nzuki, \\ ${ }^{I}$ School of Business, Kenyatta University \\ ${ }^{2}$ Management Science Department, Kenyatta University
}

\begin{abstract}
The adoption of Enterprise Resource Planning systems (ERP's) has many business implications. The purpose of this study was to determine the factors determining adoption of ERP's among listed in the Nairobi Securities Exchange (NSE) companies in Kenya. The specific objectives of this study were; to establish the organization characteristics that determine adoption of ERP's, find out the ERP attributes that contribute to its adoption and to investigate the extent of adoption and use of ERP by listed companies in Kenya. The descriptive research design was used in this study and the sample size was the fifty five (55) companies listed at the NSE. Study data was collected using a questionnaire developed by the researcher and administered with the help of a trained research assistant. The data was analysed through SPSS software and results presented in percentages and frequencies through tables and figures. The results indicated that the size of the firm, number of employees in organizations, employee turnover, location, and type of ownership of the organization, age of the company, capital structure and familiarity with ERP tools influenced organizations adoption of ERP systems. ERP attributes like its complexity and compatibility, triability, Observability, relevance and interest within businesses for the adoption of the ERP systems led to the adoption of the system. The ICT environment aspects included hardware, software, people, the government, politics, the environment and innovation. These findings are relevant to the government in its implementation of the vision 2030 as well as to the companies listed in NSE.
\end{abstract}

\section{Introduction}

An in-depth analysis of the evolving adoption of information systems (IS) showed that they have gradually spread to all organizational levels (Raymond and Sylvestre, 2007). All forms of business management practices cut across a large number of users in different managerial levels in the organization. The global development of IS had been necessitated by the different operational units or functions of the enterprise. Every function developed its own applications making various systems coexist in the same organization without any communication between them. This lead to the birth of "informational fragmentation" (Muscatello et al., 2003). Similarly, Beretta, (2002) termed the phenomena as "functional silos" being a summation of dysfunction, redundancy and waste in utilization of information systems.

There was great importance for IS integration in the modern organization which lead to the need to manage data on competition, products, markets, customers and technological developments (Al-Mashari et al., 2003). Enterprise Resource Planning (ERP) systems, or more recently Enterprise Systems (ES), have been perceived by organizations as a solution to this problem (Davenport, 1998). ERP systems if well adopted in many organizations brought in many benefits. An ERP system is an integrated software package that manages an organization's operations and resources. By integrating all departments and functions of the organization into a single computer system, it serves the different departmental needs (Botta-Genoulaz and Millet, 2005).

ERP systems provided organizations with various benefits, such as; substantial tangible benefits, such as inventory reduction, data integration, fewer personnel needed and reduced information technology (IT) costs. There were also intangible benefits, such as improved internal processes, better customer service and strategic enhancements (Davenport, 2000; Umble et al., 2003; Al-Mashari et al., 2003). The extent of adoption of majority of the leading ERP vendors (SAP, Oracle, PeopleSoft, JD Edwards, and Baan) mainly targeted the big corporates with more than 1,000 employees (van Everdingen et al., 2000, Kremers and Dissel, 2000). Most have already adopted ERP systems, and are now enjoying the benefits. Small and medium-sized firms have also discovered and started adopting ERP systems although they point out high implementation costs in comparison to their scarce resources as some of the leading factors affecting adoption. Other factors include lack of the necessary experience for adopting ERP systems effectively (Rao, 2000).

A listed company is a public company that offers its securities for sale to the general public through a stock exchange. Companies that have operated for a long time have viewed going public as beneficial because they have longer operating histories thus facing less uncertainty (Carter 1998). In the recent past, several companies have been listed at the Nairobi Securities Exchange, increasing the number of listed companies to 55 ("listed companies," n.d). These were drawn from different sectors of the Kenyan economy. The decision to go 
public improved the liquidity of a Company's shares as well as the scope for diversification by the initial shareholders of the company. It also improved the positive public image due to better management (UNCTAD, 2003)

According to United Nation Conference on Trade and development (2003), for a long time, disclosure requirements were insufficient and there was inadequate protection of investors. In 2002 the Capital Markets Authority, working with the Nairobi Stock Exchange, developed a new legal and regulatory framework that confirmed to the best international practices. These rules required quarterly reports as opposed to the previous half yearly ones. All these rules and regulations have necessitated most of the listed companies at the Nairobi stock exchange to adopt some of the best information systems such ERPs for reporting purposes as a way of ensuring compliance and trying to gain competitive edge in the market.

The evaluation of the contribution of ERP systems in terms of both value creation and economic returns was a difficult task, because of the extent of the organizational changes (Lozinsky, 1999; Shtub, 1999; Willcocks and Lacity, 1998) to which their implementation leads, as well as the difficulties in predicting the return on investment (Mabert et al., 2001). One of the most misleading legacies of traditional software project management was that the company expected to gain value from the use of the software application as soon as it was installed (Al-Mashari et al., 2003). Since the adoption of an ERP system requires extensive efforts, both for the technological and business aspects of the implementation, neither information technology (IT) practitioners nor researchers have developed a deterministic method to evaluate the related impacts (Al-Mashari, 2002). The adoption of ERP systems in Kenya was not on the upper side.

For instance in June 2006 Uchumi supermarket chain closed down admitting it was insolvent.The over ambitious expansion strategy and the poor installation of the ERP system were cited by expert as some of the reasons which contributed to the insolvency. The Uchumi supermarket experience was an example that there was an urgent need for understanding ERP implementation in less Developed countries, and in Kenya in particular because this system was still in their early stages of development.

The study sought to;

i. Establish the organizational characteristics that influenced adoption of ERPs by companies listed at the Nairobi Stock Exchange (NSE).

ii. Determine the ERP attributes that affected adoption of ERP's by companies listed at the Nairobi Securities Exchange.

iii. Identify the influence of ICT environment on adoption of ERPs by companies listed at the Nairobi Securities Exchange during adoption of ERPs.

\section{Research Methodology}

The research design to be used was descriptive survey because it provided the best answers when "how" or "why" questions are raised in a study. Being the most preferred method, it enabled the investigator achieve her objectives even with little control over events surrounding the research problem (Frederickson, 1996). ERP adoption is a new concept in the business world and was to be studied within a real-life context. The researcher targeted population consisted of 55 companies listed at the NSE in Kenya. This represented ten different market segments. The researcher conducted a census of all the companies listed at the NSE to find out the extent and factors they considered in adoption of ERPs.

The area of study comprises of Companies Listed at the Nairobi Securities Exchange. The Nairobi Securities Exchange comprised approximately 55 listed companies with a daily trading volume of over USD 5 million and a total market capitalization of approximately USD 15 billion. Aside from equities, Government and corporate bonds were also traded on the Nairobi Securities Exchange. Automated bond trading started in November 2009 with the KES 25 billion KenGen bond.

Average bond daily trading was USD 60m. Trading hours were from 09:00 to 15:00. Delivery and settlement was done via an electronic Central Depository System (CDS) which was installed in 2005. Settlement was $\mathrm{T}+3$, on a delivery-vs-payment basis. The daily price movement for any security in a single trading session was not be more than $10 \%$ except during major corporate announcements. The companies listed form an integral part in the growth of the economy. Their leadership in adoption of ERP greatly increased the rate at which businesses are automated and thereby lead to growth.

This study being a survey relied on primary data that was collected from the respondents. The respondents were the senior managers and those in charge of information communication technology in the companies listed at the NSE. The researcher administered the questionnaire which was divided into three sections. To ensure data was collected expeditiously, the questionnaires were administered on a "drop-and-pick" method coupled with telephone and email follow ups. Care was taken in the design of the questionnaires to ensure that the questions obtained accurate answers to the research questions and were able to address the research objectives 


\section{Results and discussions}

\subsection{Organizational Characteristics Influencing the Adoption of ERP Systems}

The study also sought to find out whether the companies used ERP systems and according to the results, a majority of $97 \%$ noted that their companies used the systems while $3 \%$ observed that the systems were not in use in the organizations. The duration that the ERP system had been used within the organizations ranged as $15.2 \%$ noted that it had been in use for less than 3 years, $75.8 \%$ observed that it was for a period of between $3-5$ years, $3 \%$ said it was between $5-7$ years while the remaining $6.1 \%$, were of the view that the system had not been in use at all.

In a bid to find out the persons who had access to the ERP systems in the companies, the study findings showed that all staffs had access as shown by the majority of the respondents at $75.8 \%$. However $3 \%$ were of the opinion that the finance staffs had access, $12.1 \%$ said the senior staffs of the organizations, $3 \%$ observed that only the procurement/purchasing staff and senior staff, 3\% noted that the finance staff and procurement/purchasing staff had access to the system while the remaining 3\% found the question not applicable to them.

The respondents to this study also observed that ERP systems were very relevant to a large extent in meeting their organizations business objectives as $54.4 \%$ of the participants observed, $39.4 \%$ were of the opinion that it was just relevant, $3 \%$ noted that it was moderately relevant while the remaining $3 \%$ said the question was not applicable.

The respondents whose companies were not using ERP systems noted that their organization had plans to adopt the ERP system. These same respondents noted that the production section of their organization was the only one earmarked for ERP adoption. The respondents who observed that they lacked the ERP systems in place in their organizations said that they lacked the systems there were no good objectives in place geared towards the use of ERP in their organization. The study found out that several ERP systems were in use within the companies as $27.3 \%$ of the respondents observed that SAP were the ERP systems adopted by their company, $9.1 \%$ said they adopted J.D. Edwards was adopted, a majority of 39.4\% said oracle, $3 \%$ said people soft, $15.2 \%$ said SAP and oracle 3\% said JD Edwards and oracle while the remaining 3\% said ACCRAL was the adopted system.

There are several ERP functions that can be implemented in a company and for all the respondents, different functions or modules of the system were in place in their organizations, the majority of $84.8 \%$ had all the ERP functions implemented and working in their organization, $3 \%$ had financial accounting, management account and payroll were in place, 3\% mentioned finance accounting, management accounting, material management, procurement and human resource management payroll workflow mentioned, 3\% noted financial accounting, human resource management and payroll, 3\% observed that financial accounting, management accounting, production management, payroll while the remaining 3\% participants noted that financial, management, procurement, human resource management, payroll and customer care.

The extent of application of other systems besides ERP systems varied as in some companies applied these systems to a very great extent $27.3 \%$ others making the majority of $57.6 \%$ mentioned and $15.2 \%$ mentioned that other systems besides the ERP were moderately being used in their organization. Based on the study, results indicate that the size of the firm affected the adoption of the ERP applications to a very great extent as mentioned by $60.6 \%$ who were the majority, in others the size of the firm affected the adoption of the application to a great extent as mentioned by $24.2 \%, 6.1 \%$ noted that the size of the firm affected the adoption moderately while the remaining $9.1 \%$ found the question not applicable.

The number of employees in organizations in to a very great extent affected the adoption of ERP application as $51.5 \%$ of the study participants noted, another $36.4 \%$ said it affected to a great extent, $3 \%$ said it moderately affected adoption while $9 \%$ observed that the question was not applicable.

Another factor that was found to affect the adoption of ERP applications was employee turnover as $21.2 \%$ mentioned that it affected the adoption to a very great extent, $66.7 \%$ mentioned it affected the adoption to a great extent, other respondent $3 \%$ mentioned it affected the adoption moderately while the remaining $9.1 \%$ mentioned that the question was not applicable. According to the results of the study, $6.1 \%$ mentioned that the location of the organization influenced the adoption of ERP application in a very great extent; a majority of $39.4 \%$ influences adoption to great extent, $24.2 \%$ mentioned it had moderate influence, $18.2 \%$, said it had slight influence while the remaining $12.1 \%$ noted that the question was not applicable. Type of ownership of the organization also influenced the adoption of ERP applications by companies as $24.2 \%$ said that it influenced the adoption of the ERP system, another $24 \%$ said if affected to a great extent, $21.2 \%$ said it did so moderately, $21.2 \%$ said it had little influence while $9.1 \%$ had no opinion to give on this.

Based on the findings of the study, $12.1 \%$ said that the age of the company influenced the adoption of ERP systems to a very great extent, a majority of $45.5 \%$ said it greatly influenced, $33.3 \%$ were of the opinion that it moderately influenced while $9.1 \%$ held no view on this issue as they found it not applicable. The research further attempted to find out the influence of the capital structure on the adoption of ERP applications by the 
company under study and the results showed that $24.2 \%$, of the respondents were of the opinion that it influenced the adoption to a very great extent, majority of $51.5 \%$ said it did to a great extent, $12.1 \%$ held the view that it moderately influenced, $3 \%$ said it had little influence while $9.1 \%$ said the question was not applicable. The study at the same time sought to determine how familiarity with ERP tools influenced its adoption and the results indicated that $18.2 \%$ of the participants felt that it influenced the adoption to a very great extent, most of the respondents $51.5 \%$ said it influenced ERP to a great extent, $18.2 \%$ said it influenced it moderately while $12.1 \%$ said this question was not applicable.

\subsection{Extent at Which ERP Attributes Influence its Adoption by Firms}

On a different note, the research tried to determine ways in which ERP attributes influenced its adoption and findings indicate that $33.3 \%$ of the respondents believed that the relative advantage of the ERP influenced its adoption to a very great extent, majority of $60.6 \%$ noted that in had a great influence, $6.1 \%$ said they found the inquiry not applicable. The complexity of the ERP system attributes was found to influence its adoption to a very great extent as observed by $21.2 \%$ of the respondents, $33.3 \%$ said it greatly influenced, a slight majority of $39.4 \%$ observed that it influence to a moderate extent, $3 \%$ noted that it had little influence while the other $3 \%$ had no opinion.

The compatibility of ERP attributes was found to influence ERP adoption to a very great extent as $18.2 \%$ of the participants noted, a majority of $51.5 \%$ were of the opinion that it influenced to a great extent, $27.3 \%$ said it was to a moderate extent whiel $3 \%$ had no opinion.

According tot the observation of the stujdy respondents, the triability attributes of the ERP applications and or systems contributed to a very great extent to its adopion as mentioned by $15.2 \%$ most $\mathrm{f}$ the participants $39.4 \%$ said that if influenced to a great extent, $24.2 \%$ it moderately influenced adoption, $18.2 \%$ said it had little influence. The Observability attribute of the ERP systems was found to also affect its adoption in the firms, $21.2 \%$ said that Observability influence the firms decision to adopt ERP to a very great extent, majority of $39.4 \%$ said it had a great influence, $18.2 \%$ noted that it contributed to a moderate extent and the remaining $18.2 \%$ said it had little influence.

The results obtained in this study also indicate that the irrelevance of the ERP system for business influenced the adoption of the system in some businesses as $3 \%, 1$ said this had a very great influence on the adoption of the system, $24.2 \%$ said it influenced greatly, majority of $39.4 \%$ said that it moderately influenced, $6.1 \%$ noted that it had little influence while $24.2 \%$ observed that this attribute had no influence at all in the adoption of ERP systems in their businesses. Increased interest within businesses for the adoption of the ERP systems led to the adoption of the system to a very great extent as mentioned by a majority of $51.5 \%$ of the study participants, it also influence adoption to a great extent as $42.4 \%$ observed, $3 \%$ noted that it had moderate influence. However according to the respondents apart from the mentioned attributes no other attributes influenced its ERP adoption in their firms.

\subsection{Extent at which ICT Environment Aspect Determine the Adoption of ERP Systems}

The results of this study showed that the ICT environment aspect determined whether firms adopted the ERP systems in the firms or not. According to the findings, majority of the respondents $78.8 \%$ noted that the hardware determined the adoption to a very great extent, $15.2 \%$ observed that it had a great influence, and $3 \%$ observed that hardware determined the adoption of the ERP system to a moderate extent. Another aspect of ICT that influenced ERP adoption was software and as the participants observed, $72.7 \%$ making the majority were of the view that the software influenced to a great extent the adoption of ERP by firms, $21.2 \%$ sad it had great influence on the adoption, $3 \%$ said it had moderate influence.

As findings show, the study found that the ICT environment of people influenced to a very great extent the adoption of ERP system to a very great extent as mentioned by $54.5 \%$ respondents, the study also shows that this aspect influences the adoption to a great extent as $39.4 \%$ observed while $3 \%$ were of the opinion that people influence ERP adoption very moderately. The other ICT environment aspect that was found to influence the adoption of ERP systems by the firms was the government. This aspect was shown to influence the adoption to a very great extent by $21.2 \%$ of the research participants, a majority of $54.5 \%$ observed that the government influenced the adoption to a great extent, $18.2 \%$ said it had moderate influence while $3 \%$ said influence to a little extent.

Politics is another aspect of ICT that this study found to have certain influence on the adoption of ERP systems by firms as $15.2 \%$ observed that it had a very great influence, majority of $51.5 \%$ noted that it greatly influenced, $21.2 \%$ said it moderately influenced while $9.1 \%$ said it had little influence. The environment in itself was also another aspect mentioned by the participants as a component of ICT environment that influenced the adoption of ERP systems by firms. Based on the findings, 27.3\% noted that environment influenced the adoption to a very great extent, a majority of $42.4 \%$ said that it had a great influence, $21.2 \%$ said it had moderate influence while $6.1 \%$ observed that the environment had little influence on the ERT system adoption by the firms. 
The last aspect of the ICT environment that was found to influence the adoption of the ERP system by organization was innovation which according to $33.3 \%$ of the study participants influenced the adoption to a very great extent, majority of $54.5 \%$ said it influenced application of ERP system greatly while $9.1 \%$ observed that it influenced the implementation of ERP systems to a moderate extent. Based on the findings, there were no other ICT environment aspects that were in play that influenced the adoption of ERP systems.

\section{Conclusion and Recommendations}

As the study results show, several companies have in place ERP systems in their organization with the production section being earmarked for ERP. The ERP systems varied from one company to the next however several ERP functions were implemented by the organizations under study but majority had all the functions in place while other had different combinations of ERP functions in place. Several factors were found by the study to determine the adoption of the ERP systems amongst the companies listed in the NSE while as the results also show many attributes also influenced the adoption of ERP by the companies to a very great extent. Lastly the ICT environment was also found to influence the adoption by all the companies as the study results showed.

The recommendations arising out of this study include taking urgent proactive measures are to improve the use of ERP within all the companies listed in the NSE in Kenya. This can be achieved by addressing all information aspects of the companies or all departments that require the use of ERP systems. They should be accorded one relevant ERP system to be installed and used in appropriate departments/area. There are various ICT environmental challenges that need to be dealt with urgently. They are affecting or influencing the applicability of ERP to a great extent.

\section{References}

[1]. Al-Mashari, M., Al-Mudimigh, A. and Zairi, M. (2003), "Enterprise resource planning: a taxonomy of critical factors", European Journal of Operational Research, Vol. 146 No. 2, pp. 352-64.

[2]. Beretta, S. (2002), "Unleashing the integration potential of ERP systems: The role of process- based performance measurement systems", Business Process Management Journal, Vol. 8 No. 3, pp. 254-77.

[3]. Burt, R.S. (2004), Structural holes and good ideas, American Journal of Sociology, 110, 349-400

[4]. Collis, J. and Hussy, R. (2003).Business Research, 2nd Edition, Palgrave Macmillan, Basingstoke.

[5]. Davenport, T.H. (2000), "The future of enterprise system-enabled organizations", Information Systems Frontiers, Vol. 2 No. 2, pp. 163-80.

[6]. Davenport, T. H. (1998). Putting the enterprise into the enterprise system.Harvard Business Review, 76( 4), 121-131.

[7]. DiMicco, J., Millen, D.R. 2008.'Motivations for social networking at work'. Proceedings of the ACM 2008 Conference on Computer Supported Cooperative Work, San Diego, CA, USA, ACM Digital Library,711-720

[8]. Eardley, A., Shah, H., \&Radman, A. 2008.A model for improving the role of IT in BPR.Busines Process Management Journal, $14(5), 629\{653$.

[9]. Esteves, J.M., Pastor, J. and Casanovas, J. (2003), "A goal/question/metric research proposal to monitor user involvement and participation in ERP implementation projects", paper presented at Information Resources Management Association Conference (IRMA), pp. 325-7.

[10]. Everdingen, Y.V., van Hillegersberg, J. and Waarts, E. (2000), "ERP adoption by European midsize companies", Communications of the ACM, Vol. 43 No. 4, pp. 27-31.

[11]. Ginzberg, Michael J. "Key Recurrent Issues in the MIS Implementation Process,” MIS Quarterly, 5 (1981): $47-59$.

[12]. Granovetter, M. S. (1973). The Strength of weak ties. American Journal of Sociology, 78, 1360-1380.

[13]. Granlund M., Malmi, T. (2002), Moderate impact of ERPS on management accounting: a lag or permanent outcome?, in Management Accounting Research, n.13.

[14]. Günther, O., Krasnova, H., Riehle, D., \&Schondienst, V. (2009).Modeling Micro blogging Adoption in the Enterprise. Americas Conference on Information Systems (pp. 1-10). San Francisco, California

[15]. Gupta, O., Priyadarshini, K., Massoud, S. and Agrawal, S.K. (2004). Enterprise Resource Planning: A case of a Blood Bank, Industrial Management and Data System, 104 (7), pp.589-603.

[16]. Hammer, M. and J. Champy. 2001, 'Reengineering the Corporation: A Manifesto for Business Revolution', Harper Business, New York, NY, USA

[17]. Ibrahim, A. M,.S (2007). Implementation of ERP in Libyan Public Sector Organizations, PhD Thesis, University of Salford.

[18]. Jacobs, F. and Weston, R.F.C. (2007), "Enterprise resource planning (ERP) - A brief history", Journal of Operations Management, Vol. 25 No. 2, pp. 357-63.

[19]. Kohli, R. and Hoadley, E. (2006), "Towards developing a framework for measuring organizational impact of it-enabled BPR: case studies of three firms", The Data Base for Advances in Information Systems, Vol. 37 No. 1, pp. 40-58.

[20]. Langenwalter, G.A. (2000). Enterprise Resources Planning and beyond: Integrating Your Entire Organisation, St. Lucie Press, Florida.

[21]. Loh T. C. and Koh S. C. 2004. 'Critical elements for a successful enterprise resource planning implementation in small- and medium-sized enterprises', International Journal of Production Research, 42(17) 3433-3455.

[22]. Lozinsky, S. (1999), Enterprise-wide Software Solutions: Integration Strategies and Practices, Addison-Wesley Professional, Reading, MA.

[23]. Mabert, V.A., Soni, A. and Venkataramanan, M.A. (2001), "Enterprise resource planning: common myths versus evolving reality", Business Horizons, Vol. 44 No. 3, p. 69.

[24]. Mandal, P. and Gunasekaran, A. (2003). Issues in Implementing ERP: A Case Study, European Journal of Operational Research, 146(2), pp. 274-283.

[25]. Melone, Nancy P. "A Theoretical Assessment of the User-Satisfaction Construct in Information Systems Research,” Management Science, 36 (1990): 76-91.

[26]. Murray, M. and Coffin, G. (2001), "A case study analysis of factors for success in ERP system implementations", Proceedings of the Seventh Americas Conference on Information Systems, Boston, MA, pp. 1012-8. 
[27]. Nah, F.F-H., Zuckweiler, K.M., (2003) 'ERP implementation: chief information officers' perceptions of critical success factors', International Journal of Human-Computer Interaction, 6(1): 5-22.

[28]. Otieno, J.O,(2010), "Enterprise Resource Planning Systems Implementation and Upgrade: A Kenyan Study,” School of Engineering and Information Sciences Middlesex University.

[29]. Pagano, M., Panetta, F. and Zingales, L. (1998). Why do companies go public? An empirical analy sis, Journal of Finance, LIII (1) 27-64

[30]. Parkinson, J.N. (1984). "The Nairobi Stock Exchange in the context of development of Kenya". Savings and Development, VIII (4), p363-372.

[31]. Rao, S.S. (2000), "Enterprise resource planning: business needs and technologies", Industrial Management \& Data Systems, Vol. 100 No. 2, pp. $81-8$.

[32]. Raymond, L. and Sylvestre, U. (2007), “A profile of ERP adoption in manufacturing SMEs",Journal of Enterprise Information Management, Vol. 20 No. 4, pp. 487-502.

[33]. Remus U. 2006.'Critical Success Factors of Implementing Enterprise Portals'.Proceedings of the 39th Hawaii International Conference on System Sciences

[34]. Rosario, J.G. (2000), “On the leading edge: critical success factors in ERP implementation projects”, Business World (Philippines), May 17, p. 27.

[35]. Sekaran, U. (2000). Research Methods for Business, 3rd Edition, John Wiley, Chichester.

[36]. Shehab, E.M., Sharp, M.W., Supramaniam, L. and Spedding, T.A. (2004), "Enterprise resource planning: an integrative review", Business Process Management Journal, Vol. 10 No. 4, pp. 359-86.

[37]. Schwalbe K. 2000, 'Information Technology Project Management, Cambridge, MA.Shtub, A. (1999), Enterprise Resource Planning (ERP): The Dynamics of Operations Management, Springer, New York, NY.

[38]. Somers T.M. and Nelson K.G. 2004.'A taxonomy of players and activities across the ERP project life cycle', Information and Management, 41(3):257-278.

[39]. Sprott, D. (2000), "Componentizing the enterprise application packages", Communications of the ACM, Vol. 43 No. 4 , pp. $63-9$.

[40]. Umble, E.J., Haft, R.R. and Umble, M.M. (2003), "Enterprise resource planning: implementation procedures and critical success factors", European Journal of Operational Research, Vol. 146 No. 2, pp. 241-57.

[41]. United Nations Conference on Trade and Development (UNCT AD), (2003) "Case study on corporate governance disclosures in Kenya", TD/B/COM.2/ISAR/19/Add.3

[42]. Velcu, O. (2005). Impact of the Quality of ERP Implementations on Business Value.The Electronic Journal Information Systems Evaluation , 8 (3), 229-238.

[43]. Vemuri, V.K. and Palvia, S.C. (2006), "Improvement in operational efficiency due to ERP systems implementation: truth or myth?", Information Resource Management Journal, Vol. 19 No. 2, pp. 18-36.

[44]. Venkatesh, Viswanath, Morris, Michael G., Davis, Gordon B., Davis, Fred D. "User Acceptance of Information Technology: Toward a Unified View," MIS Quarterly, 27 (2003): 425-478.

[45]. V. Botta-Genoulaz and P.A. Millet, A classification for better use of ERP systems, Computers in Industry 56 (2005) $573-587$

[46]. Wei, C.C. and Wang, M.J.J. (2004), “A comprehensive framework for selecting an ERP system”, International Journal of Project Management, Vol. 22 No. 2, pp. 161-9.

[47]. Willcocks, L.P. and Lacity, M.C. (1998), Strategic Sourcing of Information Systems: Perspectives and Practices, Wiley, Chichester.

[48]. Woo, H.S. (2007), "Critical success factors for implementing ERP: the case of a Chinese electronics

[49]. Zhang L, K.O. Lee K.O, Banerjee P (2002). 'Critical Success Factors of Enterprise Resource Planning Systems Implementation Success in China'. Proceedings of the 36th Hawaii International Conference on System Sciences

[50]. Zheng S., Yen, D. C., \& Tarn, J. M. (2000).ERP and SCM. Journal of Computer Information Systems, Vol. 41, No. 1, pp. 10-84. 